\title{
Research and Practice on English Self-learning Model of Medical Profession Based on MOOC Resources
}

\author{
YANG Zhishang \\ Changsha Medical University, Changsha, Hunan,413000 China
}

284204813@qq.com

Keywords: MOOC; medical profession English; self-learning model; practice

\begin{abstract}
This paper is dedicated to English self-learning model and practice research of medical profession based on MOOC model; it constructs interactive video conference activity structure between MOOC teacher and Chinese students. This research uses medical profession English MOCC as example, it investigates and analyzes actual effect of English teaching model based on MOOC medical profession, it makes analysis through English self-learning model research and practice based on MOOC resources.
\end{abstract}

\section{Introduction}

In the MOCC development trend, university, enterprises and government have invested plenty of funds in constructing plenty of opening online courses with high quality, how to apply these excellent course resources to service for university face-to-face teaching of university is the focus at present. In the actual teaching, there are many foreign countries have integrated MOOC into the traditional class teaching to strengthen and enrich learning experience of students and improve learning effect.

According to whether MOCC is accord with local course or not and integration level, Holoteseu etc divided medical profession English self-learning model based on MOOC resources into 2 kinds: 1. sync integration, including sync partial integration, sync complete integration, sync multi integration. 2. Asynchronous integration, including asynchronous partial integration, asynchronous complete integration, asynchronous multi integration.

Israel divided medical profession English self-learning model based on MOOC resources into choosing one MOOC and choosing multi MOOC, it is divided into 5 kinds on this base, of which model 1 and model 2 means using the selected MOOC to replace traditional campus courses, model 3, model 14 and model 5 means using the selected MOOC as textbook and complementary of traditional course. According to characteristics of xMOCC and cMOCC, Anders divided medical profession English self-learning model based on MOOC resources into 3 kinds: admixture based on content and admixture based on social networks. The following paper makes classified analysis from perspective of content and platform: from content perspective, we divide medical profession English self-learning model based on MOCC resources into 2 kinds according to degree of MOOC integration to traditional face-to-face teaching: dominated-MOCC model and dominated face-to-face model. Of which, characteristics of the former means teachers usually choose one or more complete MOCC to require students to participate in all the online learning activities of MOCC, face-to-face teachers only organize some face-to-face offline activity to assist and enrich online learning content and activity of students. This requires students to track MOOC content and complete all the tasks, while class face-to-face time released by MOOC just surrounds MOOC content to organizes class discussion, interaction and learning based on project etc. in the face-to-face dominated admixture teaching based on MOOC, local teachers still mainly uses traditional face-to-face courses, they just use MOOC as one kind of excellent resources to assist and complement traditional face-to-face courses. From platform perspective, we divide medical profession English self-learning model based on MOOC into original MOOC-dominated platform and local-dominated teaching platform according to network teaching platform used by local teachers. Of which, original MOOC-dominated platform admixture 
teaching means local teachers only provide links of original MOOC platform courses, all or the main online learning activities take place in the original MOOC platform. For example, in the admixture teaching of local-dominated teaching platform, medical profession English self-learning model research and practice based on MOOC resources can flexibly organize online learning activity. Through comprehensive analysis, at present, all these medical profusion English self-learning model and practice based on MOOC resources universally has one problem: it lacks of interaction between students and MOOC teachers, especially lacks of direct real-time deep interaction, while this problem is universal when foreign teachers voluntarily apply MOOC into face-to-face course.

\section{Medical profession English Self-learning and Teaching Target Analysis Based on MOOC Resources}

A. Learning component of medical profession English self-learning based on MOOC resources

Seeing learning component of medical profession English self-learning based on MOOC resources from perspective of technology and teaching media, it manly includes sync physical way, sync online way as well as self-peace and asynchronous way etc, which is indicated by table 1 .

Table 1 Learning component of medical profession English self-learning base on MOOC

\begin{tabular}{|c|c|}
\hline component & detailed content \\
\hline sync physical from & $\begin{array}{l}\text { teacher-dominated lecturing class and teaching } \\
\text { hands-on laboratory and workshop } \\
\text { workshop practice }\end{array}$ \\
\hline $\begin{array}{l}\text { Synchronous online } \\
\text { form } \\
\text { (real-time e-Learning }\end{array}$ & $\begin{array}{l}\text { electronic conference } \\
\text { visualzied classroom } \\
\text { conference and broadcast based on Web } \\
\text { online instruction } \\
\text { instant message }\end{array}$ \\
\hline $\begin{array}{l}\text { self-peace and } \\
\text { asynchronous form }\end{array}$ & $\begin{array}{l}\text { file and website } \\
\text { trainig module bsaed on Web or computer } \\
\text { evaluate test and investigation } \\
\text { simulation } \\
\text { work instruction and electronic performance support system } \\
\text { recorded instant class } \\
\text { online learning community and online discussion }\end{array}$ \\
\hline
\end{tabular}

Understanding from teaching and learning, mixed learning component includes face-to-face traditional class learning and digitalized learning under virtual environment. In the actual teaching application, we should determine mixed component to obtain the optimal benefit of teaching according to objective factors such as teaching target, teaching resources etc.

Table 2 Teaching stage

\begin{tabular}{|c|l|}
\hline teaching stage & \multicolumn{1}{c|}{ effect } \\
\hline course import & $\begin{array}{l}\text { promote teachers and students to achieve common view in teaching } \\
\text { target, course content, network class organization form, learning } \\
\text { support method and test evaluation method etc of course }\end{array}$ \\
\hline actiivty organization & $\begin{array}{l}\text { provide ability in testing correctness of understanding knowledge, } \\
\text { cultivating and exploring, cooperating etc }\end{array}$ \\
\hline learning support & $\begin{array}{l}\text { in order to solve shortages of learning skills or help learners to } \\
\text { overcome difficulty during learning, it provides academic or } \\
\text { non-academic help }\end{array}$ \\
\hline teaching evaluation & check and evaluate predicetd teaching effect is teaching evaluation \\
\hline
\end{tabular}


Because online learning of medical profession English self-learning mode based on MOCC resources needs computer or support from portable equipment, we should understand computer allocation condition of learners. Figure 1 indicates about 92\% students have personal computers, nearly 6\% students have none, but they can use computers through other channels, there are just $2 \%$ students have no condition to use computer, but they can carry out online learning through portable equipment. From this we can see that the participated students all have condition of learning by surfing internet, which provides good base for the smooth development of mixed learning in the future.

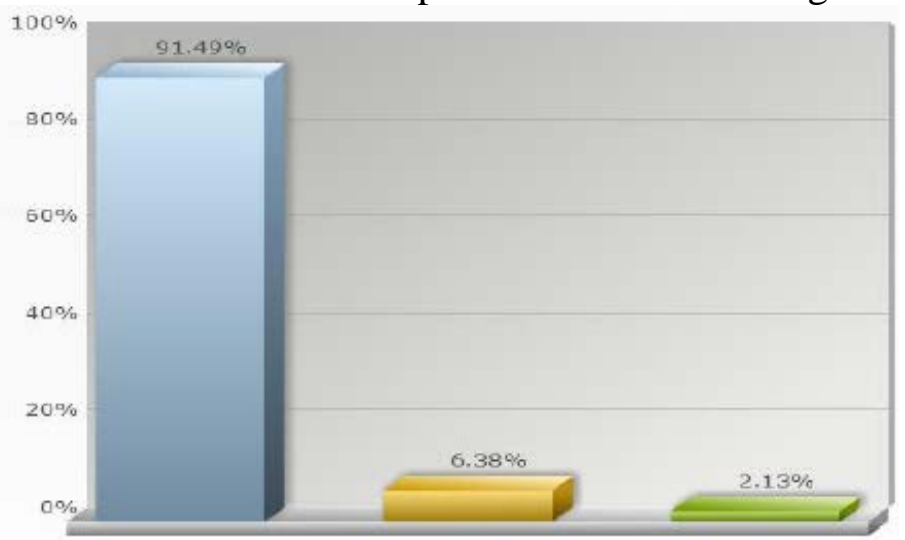

Figure1 Compute allocation condition diagram of students

2 pieces of fold line in figure 2 respectively represents frequency of learners of using internet to search information and frequency of participating in class discussion. From figure we can directly find that the frequency of learners of using internet to search information is relatively higher, which indicates that most students have universally used internet, it provides convenience to life and study by internet search. The other fold line reflects self-evaluation on participating in class discussion, it generally concentrates on the common area, which indicates most students are in the passive situation in class teaching, they will not actively participate in discussion, so we need to create condition and guide students to discuss.

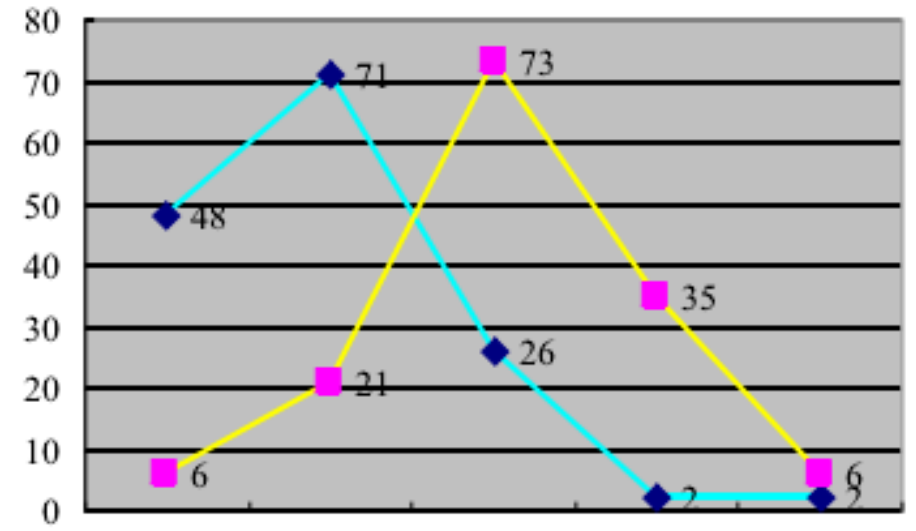

Highest high common low lowest

$\downarrow$ search frequency of network information class discussion frequency

Figure 2 Network information search of learners and condition of class discussion frequency

One biggest characteristic of MOOC is it uses micro-video resources to teach in the teaching process. Micro-video resources derives from network video course resources in the past, with technology of learning media becomes mature, construction of education resource cloud and gradual popularization and application of portable intelligent terminal, which provides strong and powerful technology support and guarantee for the development and application of micro-video resources. Once there are researchers make analysis on 862 videos and 7 millions observation action of 4-gate MOCC in edX platform, they have drawn standard distribution diagram on time of students watching videos(the horizontal line in the middle represents mid-value), which is indicated by figure 3 . From figure we can see in the 3 given video length areas, video of 6 to 9 minutes is easy for students to watch through, 
accordingly, the probability of knowledge presented in these videos mastered by students has greatly increased, this provides certain scientific base for MOOC to use micro-video resources to teach.

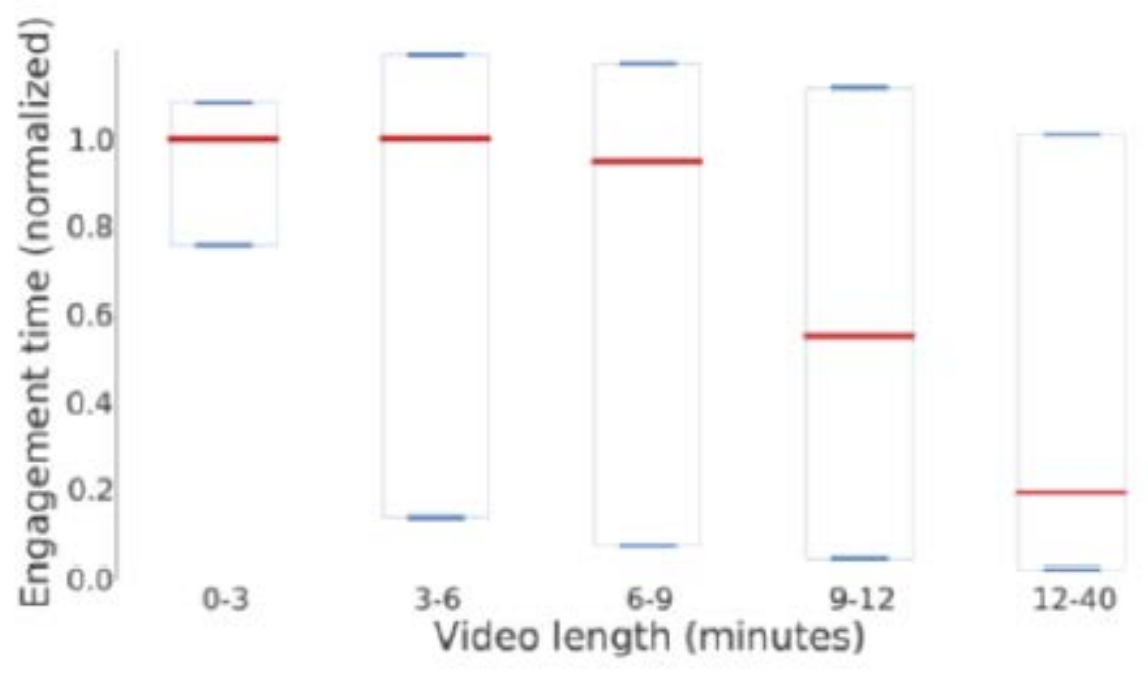

Figure 3 Standard distribution diagram of watching video time for students

\section{B. Activity organization of class learning}

From form, blended learning is composed of a series of learning activities, w hile learning activity is completed under organization of teachers, so teachers take active effect in development of mixed learning, the most obvious is guidance on class teaching. In the blended learning, the final achievement of students is not only indicated in exam marks, it is also indicated in class vitality. Class learning is the important part of blended learning, one good actiivty deisgn takes key effect in developing class learning. Class teaching in blended learning emphasizes guidance from teachers, expansion of students thinking, which needs teachers to deisgn one good discusison topic. Only make students actively participate in learning, work hard to complete learning tasks, experience learning pleasure, belended learning effect like this will be ideal. So realization of teaching target, control of learning progress etc needs to be indicated in detailed learning activities. In the blended learning based on MOOC, it arranges class face-to-face lecture of 5 times, it mainly deisgns class lecturing, discusison communication, refelction, reading etc, the details are indicated by table 3 .

\begin{tabular}{|c|c|c|}
\hline & topic & main activty \\
\hline $\begin{array}{l}\text { the first } \\
\text { week }\end{array}$ & $\begin{array}{l}\text { import course, it mainly } \\
\text { introduces MOOC } \\
\text { platform registration and } \\
\text { operation } \\
\end{array}$ & $\begin{array}{l}\text { 1Class lecturer makes description on relevant course } \\
\text { structure and learning way } \\
2 \text { Discuss effect of MOOC on higher education }\end{array}$ \\
\hline $\begin{array}{l}\text { the } \\
\text { frouth } \\
\text { week }\end{array}$ & $\begin{array}{l}1 \text { introduce notes of course } \\
2 \text { Introduce effect of } \\
\text { English crisis } \\
3 \text { Beautiful soul of queen } \\
\text { of science }\end{array}$ & $\begin{array}{l}1 \text { Class lecturer makes summary on learning condition of } \\
\text { the former } 3 \text { weeks and makes explaination on knoweldge } \\
\text { points related to course exercise. } \\
\text { 2Discuss and exchange discusison topic: beautiful soul of } \\
\text { queen of science is indicated in which aspect, students make } \\
\text { discusison by way of group and then share it. Finally, } \\
\text { students exchange with teachers and fellows on difficulty } \\
\text { meet in relevant learning. }\end{array}$ \\
\hline $\begin{array}{l}\text { the } \\
\text { seventh } \\
\text { week }\end{array}$ & $\begin{array}{l}\text { 1, interesting question and } \\
\text { answer } \\
2 \text { Development state of } \\
\text { English in China }\end{array}$ & $\begin{array}{l}1 \text { Class teacher makes summary on learning condition of the } \\
\text { first } 3 \text { weeks and makes explaination on knowledge points } \\
\text { related to course exercise. } \\
2 \text { Problem solution: teacher proposes interesting English } \\
\text { problems in class, students consider and answer it, teacher } \\
\text { makes evaluation. } \\
3 \text { Discuss and exchange development state of English in }\end{array}$ \\
\hline
\end{tabular}




\begin{tabular}{|c|c|c|}
\hline & & China and make discussion. \\
\hline $\begin{array}{l}\text { the tenth } \\
\text { week }\end{array}$ & $\begin{array}{l}1 \text { How to enhance English } \\
\text { culture } \\
2 \text { Effect of English culture } \\
\text { on major }\end{array}$ & $\begin{array}{l}1 \text { Class teacher makes summary on learning condition of the } \\
\text { first } 3 \text { weeks and makes answer on relatively concerntrated } \\
\text { problems in forum. } \\
\text { 2Discuss and exchange problem discussed and exchanged } \\
\text { by teachers: what effect of English culture on major and } \\
\text { make students discuss by way of group } \\
3 \text { PPT Read relevant PPT guided by teachers. }\end{array}$ \\
\hline $\begin{array}{l}\text { the } \\
\text { twelth } \\
\text { week }\end{array}$ & review & $\begin{array}{l}1 \text { Class teaching helps students to review learned } \\
\text { knowledge points and makes summary on learning } \\
\text { condition of } 9 \text { weeks. } \\
2 \text { Discuss and exchange notes of final exam, teacher helps } \\
\text { students to make answer. } \\
\text { 3Reconsider and require students to make } \\
\text { self-reconsideration on the whole learning process, } \\
\text { summarizes the problems and how to solve, evaluate } \\
\text { learning effect. }\end{array}$ \\
\hline
\end{tabular}

\section{Conclusion}

This research is based itself upon higher-level clinical medicine talents cultivation requirement in China, it has deeply mastered knowledge ability and quality requirement of modern medicine science development and development characteristic rule of medicine on higher-level clinical talents, it is base don self-learning model research and practice of medical profession English based on MOOC, medical education cultivation model of 8 years can be universally popularized and applied

\section{References}

[1]Liu Bing, Xin Tongchun. Medical English Teaching Model Exploration Based on Flipped Classroom [J]. Northwest Medical Education, 2015, 05:845-848+855.

[2]Si Daowen, Sun Jinlian, Zhang Yuxin. Automatic Learning and Medical Learning Strategy [J]. Northwest Medical Education, 2008,06:1185-1187.

[3]Yan Xiujing, Ding Kunmin, Li Xiaowei, Yang Dan, Yang Lin, Zhang Lan. Research Application of Project Teaching Model Based on Flipped Classroom [J]. China Modern Educational Equipment,2016,13:101-104.

[4] Jiang Hui. Application of CBI Theme Model in Medical Teaching [J].Journal of MuDanJiang Medical University, 2016, 06:152-154.

[5]Wang Jian, Li Pan, Wang Wenbiao, Li Hongmin. Research on Postgraduate Medical English Course Teaching and Evaluation System Based on Formative Evaluation [J]. Continuing Medical Education,2017,06:30-33. 